\title{
Emergency Physicians' Approach to Minor Head Trauma in Pediatric Patients
}

Acil Serviste Görev Yapan Hekimlerin Minör Kafa Travmalı Çocuk Hastalara Yaklaşımı

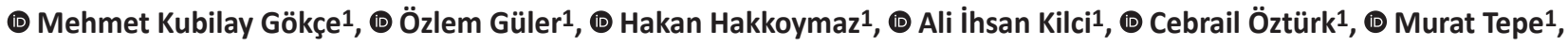 \\ (1) Evren Ekingen² \\ ${ }^{1}$ Kahramanmaraş Sütçü Imam University Faculty of Medicine, Department of Emergency Medicine, Kahramanmaraş, Turkey \\ 2Batman State Hospital, Emergency Medicine Specialist, Batman, Turkey
}

\section{Abstract}

Objectives: To investigate the use of tomography in children with head trauma by emergency department physicians, the frequency of their applying clinical decision-making rules (CDMRs), and the factors playing a role in the decision of tomography use.

Materials and Methods: Our 19 question-survey was applied to physicians working in different statuses in the emergency departments of various hospitals in our country.

Results: Three hundred and six physicians participated in our study. The rate of tomography use in pediatric patients with minor head trauma was reported by physicians as follows: One hundred and three physicians stated as 10\% or less, 60 as between $11 \%$ and 25\%, 39 as between 26\% and $50 \%$, and 104 as 50\% or more. 39.5\% of the participants stated that they applied CDMRs when making a computed tomography (CT) decision, $42.8 \%$ stated that they decided according to their clinical experience, $6.2 \%$ stated that they made the decision with the recommendation of a consultant. $36.6 \%$ of the physicians stated that they were threatened and insulted for not performing a CT scan and $6.9 \%$ stated that they were subjected to verbal and physical attacks. The reason for the increase in tomography use was defined as the fear of malpractice by $56.2 \%$, family pressure by $22.2 \%$ and desire to conclude the patients quickly in a busy working environment by $8.2 \%$ participants.

Conclusion: It was observed that the rate of application of CDMRs by physicians was low and the rate of tomography use was high. Medico-legal concerns, the pressure of families, and patient overcrowdedness in the emergency room took the top three places among the reasons for this.

Key Words: Emergency Department, Computerized Tomography, Pediatric Head Trauma, Clinical Decision-Making Rules

\section{Öz}

Amaç: Bu çalışmada acil servis hekimlerinin kafa travmalı çocuk hastalardaki tomografi kullanımlarını, klinik karar verme kurallarını (KKK) ne kadar uyguladıklarını ve tomografi kullanım kararının verilmesinde rol oynayan etmenleri araştırmayı amaçladık.

Gereç ve Yöntem: Ülkemizdeki çeşitli hastanelerin acil servislerinde farklı statülerde görev yapan hekimlere 19 soruluk anketimiz uygulandı.

Bulgular: Çalışmamıza 306 hekim katıldı. Minör kafa travmalı çocuk hastalardaki tomografi kullanım oranlarını hekimlerin 103 'ü \%10 ve altında, 60' \% \%1-25 arasında, 39'u \%26-50 arasında ve 104'ü \%50 ve üzerinde olarak belirtti. Katılımcıların \%39,5'i bilgisayarlı tomografi (BT) kararı verirken KKK'yi uyguladığını, \%42,8'i kendi klinik tecrübelerine göre, \%6,2'si konsültan önerisiyle karar verdiğini belirtti. Hekimlerin \%36,6'sı BT çekmediği için tehdit ve hakarete uğradığını, \%6,9'u sözlü ve fiziksel saldırıya maruz kaldığını ifade etti. Tomografi kullanımındaki artışın nedenini katılımcıların \%56,2'si malpraktis korkusu, \%22,2'si aile baskısı, \%8,2'si yoğun çalışma ortamında hastayı hızlı sonuçlandırma olarak tanımladı.

Sonuç: Hekimlerin KKK'yi uygulama oranlarının düşük ve tomografi çekme oranlarının yüksek olduğu izlenmiştir. Bunun nedenleri arasında medikolegal endişeler, ailelerin baskısı ve acil servisteki hasta yoğunluğu ilk üç sırayı almıştır.

Anahtar Kelimeler: Acil Servis, Bilgisayarlı Tomografi, Çocuk Kafa Travması, Klinik Karar Verme Kuralları

Address for Correspondence/Yazışma Adresi: Özlem Güler

Kahramanmaraş Sütçü İmam University Faculty of Medicine, Department of Emergency Medicine, Kahramanmaraş, Turkey

Phone: +90 5334131325 E-mail: ozlemguler81@yahoo.com ORCID ID: orcid.org/0000-0002-1444-7730

Received/Geliş Tarihi: 22.09.2020 Accepted/Kabul Tarihi: 11.03.2021

๑Copyright 2021 Ankara University Faculty of Medicine

Journal of Ankara University Faculty of Medicine is published by Galenos Publishing House.

All content are under CC BY-NC-ND license. 


\section{Introduction}

Nearly seven hundred and fifty thousand children apply to emergency services for head trauma in the United States per year (1). Traumatic brain injury (TBI) due to head trauma is the most important cause of death and disability in children worldwide. TBI causes 7,400 deaths and 60,000 hospitalizations per year for patients under 18 years old in the USA (2).

Head trauma is classified according to Glasgow Coma Scale (GCS) as; GCS 14-15 mild, GCS 9-13 moderate, and GCS 3-8 severe head trauma (3). More than $90 \%$ of patients presenting to the emergency department with head trauma are mild head trauma, while approximately $4-7 \%$ of patients have clinically significant brain injuries and less than $1 \%$ require acute surgery $(1,4)$.

Brain tomography is the standard test for emergency diagnosis of intracranial injuries (1). While the general approach for moderate and severe head trauma is using brain tomography, the use of brain tomography in patients with mild head trauma is controversial (3). Tomography use requires sedation in children, also causes radiation exposure, and increases health care costs. It was reported that the risk of cancer increases 2-3 times in the first 22 years of life due to computerized tomography (CT) imaging (5). Conversely, failure to perform tomographic imaging in a patient with a clinically indicated CT scan may lead to skipping in the diagnosis of TBI, which may harm the patient (1).

The decision using tomography in children with head trauma is often made by emergency physicians according to the clinical suspicion of TBI and has great diversity among physicians. No symptom or finding alone is a reliable marker to describe the severity of the intracranial injury $(4,5)$. Therefore, clinical decision-making rules (CDMRs) have been developed to reduce the use of tomography and to standardize the applications in children with head trauma. Of these, Pediatric Emergency Care Applied Research Network (PECARN), Canadian Assessment of Tomography for Childhood Head Injury (CATCH), and Children's Head Injury Algorithm for the Prediction of Important Clinical Events (CHALICE) are the three best known $(4,6)$.

Although there are validated CDMRs, awareness, and prevalence of these rules vary between different countries. In this study, we aimed to investigate the rate of tomography use, CDMR use, and other factors affecting the decision for tomographic imaging in pediatric head trauma among emergency medicine physicians working in Turkey.

\section{Materials and Methods}

Our study is a survey included demographic data of emergency physicians such as age, gender, title, year of professional experience, and some questions about frequency of tomography use, CDMRs use, and factors affecting tomographic imaging decision in pediatric head trauma. Consent was obtained from Kahramanmaraş Sütçü Imam University Faculty of Medicine Clinical Research Ethics Committee (date: 10.10.2018, approval number: 2018/08/01).

Practitioners, specialists, research assistants, and academicians working in emergency departments of hospitals in different regions of our country were reached and informed about our survey by using face to face, telephone, and e-mail methods. The questionnaire was completed by the physicians who agreed to participate in our survey, which consisted of 19 questions without the names and signatures of the participants. The first six questions of our questionnaire were related to the sociodemographic data of the participants. In the second part of the questionnaire, the attitudes of the physicians to the pediatric head trauma patients, and the factors affecting the tomography decision were questioned. The entire questionnaire was included in Appendix 1.

\section{Statistical Analysis}

Statistical Package for Social Sciences-20 was used for statistical analysis of the data obtained. Descriptive statistics were shown as mean \pm standard deviation for continuous variables. Categorical variables were expressed as frequency and percentage. A chi-square test was used to compare categorical variables. For comparison of continuous variables, ANOVA and independent-sample t-tests were used according to the number of groups. A p-value of less than 0.05 was considered statistically significant.

\section{Results}

Three hundred and six physicians voluntarily participated in the study between 03 October 2018 and 03 April 2019. All physicians completed our 19-question survey. The demographic data of the participants were given in Table 1 and Figure 1.

The rate of requesting tomography was independent of the physician's age $(p=0.828)$. No difference was found between the criteria based on the decision of the tomography and the age of the physician $(p=0.599)$. The rate of using CDMRs was independent of age $(p=0.808)$. Exposure to violence for not making tomographic imaging decisions wasn't related to the age of the physicians $(p=0.617)$.

The percentage of tomography requests was higher in the female gender $(p=0.020)$. The percentage of tomography use was found as $30.96 \pm 25.69 \%$ in men and $39.01 \pm 28.83 \%$ in women. Factors affecting the decision to request tomography $(p=0.874)$ and the rate of using CDMRs $(p=0.517)$ were similar in both genders. There was no difference between genders in terms of exposure to violence $(p=0.383)$. 
There was no difference in the percentage of asking for tomography among physicians working in the university hospital, public hospital, and private hospital $(p=0.919)$. The criteria used for tomography decisions in all institutions were similar ( $p=0.193$ ). The rate of using CDMRs was similar among institutions ( $p=0.303$ ). There was no difference between the institutions in terms of violence rates $(p=0.878)$.

The distribution of tomography usage rate by physicians according to the title in pediatric patients presenting with

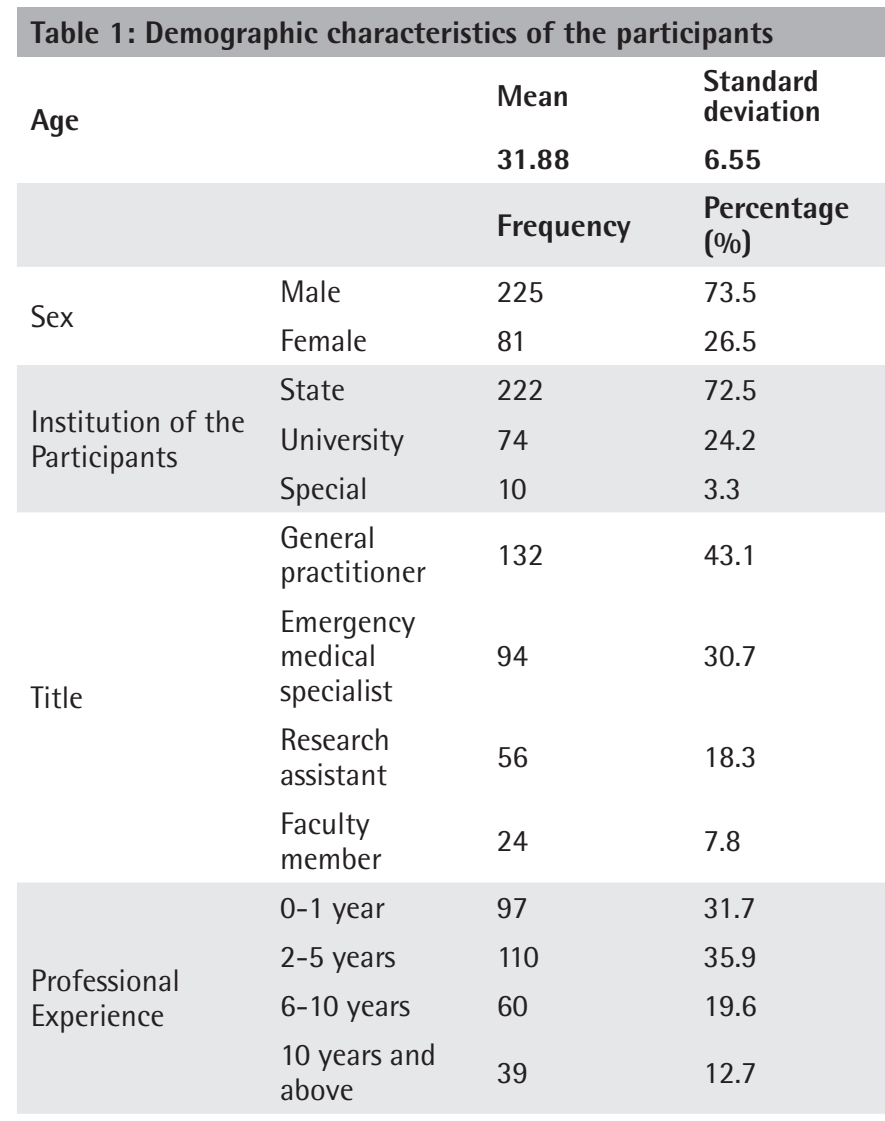

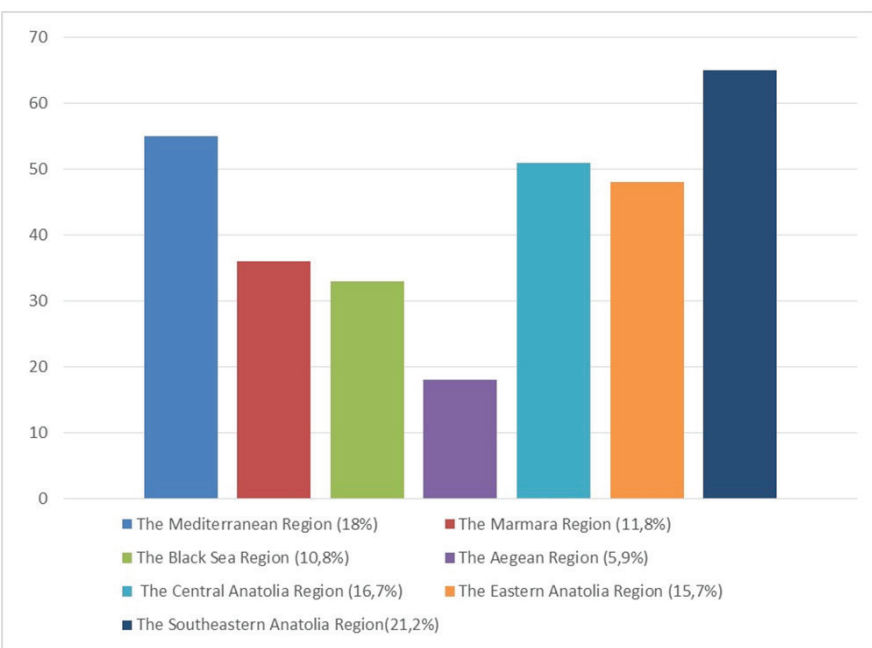

Figure 1: Distribution of participants by geographical regions of Turkey minor head trauma was shown in Table 2. No relationship was found between the titles of the clinicians and the tomography usage percentages $(p=0.800)$. The criteria used to make a tomography decision were similar in all titles $(p=0.820)$. The rate of using CDMRs did not differ by title $(p=0.303)$. Exposure rates to violence were also similar among physicians in all titles $(p=0.446)$.

Tomography usage percentages in the regions were given in Table 3. There was a significant difference between geographical regions in terms of tomography usage rates $(p<0.01)$. The percentage of clinicians requesting tomography was significantly higher in the Southeastern Anatolia Region $(p<0.001)$. The rates of using CDMRs were similar among regions $(p=0.075)$. There was no difference between regions in terms of exposure to violence $(p=0.646)$.

There was not any difference between the professional experience of the physicians participating in the study and the percentage of asking tomography $(p=0.615)$. Criteria that considered important when making tomography decisions differed with professional experience $(p<0.001)$. Physicians whose professional experience is between $0-1$ years act with the recommendation of the consultant when making a tomography decision $(p<0.05)$ and those with more than 5 years of professional experience use their clinical experience at

Table 2: Distribution of tomography usage rates according to titles

\begin{tabular}{llllll} 
& $\begin{array}{l}\text { General } \\
\text { practitioner }\end{array}$ & $\begin{array}{l}\text { Emergency } \\
\text { medical } \\
\text { specialist }\end{array}$ & $\begin{array}{l}\text { Research } \\
\text { assistant }\end{array}$ & $\begin{array}{l}\text { Faculty } \\
\text { member }\end{array}$ & Total \\
\hline $\begin{array}{l}10 \% \\
\text { and } \\
\text { below }\end{array}$ & $46(34.8 \%)$ & $32(34 \%)$ & $\begin{array}{l}17 \\
(30.4 \%)\end{array}$ & $\begin{array}{l}8 \\
(33.3 \%)\end{array}$ & $\begin{array}{l}103 \\
(33.7 \%)\end{array}$ \\
$\begin{array}{l}11 \% \text { to } \\
25 \%\end{array}$ & $32(24.2 \%)$ & $13(13.8 \%)$ & $\begin{array}{l}8 \\
(14.3 \%)\end{array}$ & $\begin{array}{l}7 \\
(29.2 \%)\end{array}$ & $\begin{array}{l}60 \\
(19.6 \%)\end{array}$ \\
\hline $\begin{array}{l}26 \% \\
50 \%\end{array}$ & $9(6.8 \%)$ & $17(18.1 \%)$ & $\begin{array}{l}11 \\
(19.6 \%)\end{array}$ & $2(8.3 \%)$ & $\begin{array}{l}39 \\
(12.7 \%)\end{array}$ \\
\hline $\begin{array}{l}50 \% \\
\text { and }\end{array}$ & $45(34.1 \%)$ & $32(34 \%)$ & $\begin{array}{l}20 \\
(35.7 \%)\end{array}$ & $\begin{array}{l}7 \\
(29.2 \%)\end{array}$ & $\begin{array}{l}104 \\
(34.0 \%)\end{array}$ \\
\hline $\begin{array}{l}\text { Total } \\
\text { Tove }\end{array}$ & $132(100 \%)$ & $94(100 \%)$ & $\begin{array}{l}56 \\
(100 \%)\end{array}$ & $\begin{array}{l}24 \\
(100 \%)\end{array}$ & $\begin{array}{l}306 \\
(100 \%)\end{array}$ \\
\hline
\end{tabular}

Table 3: Tomography usage percentages in the regions

\begin{tabular}{ll} 
Region & Tomography Usage Percentage \\
\hline The Mediterranean Region & $21.72 \pm 21.31$ \\
\hline The Marmara Region & $24.47 \pm 19.72$ \\
\hline The Black Sea Region & $21.96 \pm 18.78$ \\
\hline The Aegean Region & $44.55 \pm 25.74$ \\
\hline The Central Anatolian Region & $23.35 \pm 19.41$ \\
\hline The Eastern Anatolia Region & $33.91 \pm 32.81$ \\
\hline The Southeastern Region & $56.98 \pm 21.61$
\end{tabular}


a similar rate $(p>0.05)$. Verbal and physical assault events were also higher in the first year of the profession $(p=0.034)$.

$32.7 \%(n=100)$ of the physicians reported that 500 or less, 37.3\% ( $n=114)$ between 500 and 1000, 10.8\% $(n=33)$ between 1000 and 1500, 19.3\% ( $n=59) 1500$ or more patients are examined daily in the clinic where they were working. Hospital groups formed according to the number of patients examined daily and tomography request percentages in these groups were given in Table 4. Tomography request percentages were different from each other in hospital groups formed according to the number of patients examined daily $(p<0.001)$. Subgroup analysis of tomography request percentages between hospital groups was given in Table 5. It was determined that as the number of patients examined daily increases, the tomography demand rates increase. The number of patients examined daily is over 1000 significantly increases the percentage of tomography requests. There was a significant difference in terms of exposure to violence in the hospitals grouping made based on the number of patients examined ( $p=0.043$ ). Employees in hospitals where the number of patients examined daily are 1500 and above were found to be more verbally and physically attacked $(p<0.05)$.

93.5\% ( $n=286)$ of the physicians can perform 24-hour tomography in their clinics. Participants answered the question whether the 24-hour radiology report is written for the tomography taken in your hospital as follows: $51.3 \%(n=157)$ of the participants replied that it can be written for 24 hours, $7.5 \%(n=23)$ during working hours, $30.1 \%(n=92)$ is not written, but verbal reports can be obtained for emergency cases and $11.1 \%(n=34)$ no written or verbal report is available. There was no significant difference in the percentage of tomography

\begin{tabular}{|c|c|}
\hline $\begin{array}{l}\text { Hospitals According to the } \\
\text { Number of Patients Examined } \\
\text { Daily }\end{array}$ & $\begin{array}{l}\text { Tomography Request } \\
\text { Percentage }\end{array}$ \\
\hline$<500$ & $30.68 \pm 23.94$ \\
\hline 500-1000 & $26.57 \pm 25.49$ \\
\hline 1000-1500 & $43.33 \pm 28.33$ \\
\hline$>1500$ & $42.79 \pm 28.42$ \\
\hline
\end{tabular}

\begin{tabular}{ll|}
$\begin{array}{l}\text { Table 5: Subgroup analysis of tomography request percentages } \\
\text { among hospital groups }\end{array}$ \\
$\begin{array}{ll}\text { Comparison of Hospitals According to the Number } \\
\text { of Patients Examined Daily }\end{array}$ & p-value \\
\hline$<500-(500-1000)$ & 0.653 \\
\hline$<500-(1000-1500)$ & 0.023 \\
\hline$<500->1500$ & 0.024 \\
\hline$(500-1000)-(1000-1500)$ & $<0.01$ \\
\hline$(500-1000)->1500$ & $<0.001$ \\
\hline$(1000-1500)->1500$ & 0.960 \\
\hline
\end{tabular}

use between the clinics that can perform tomography for 24 hours and those that can not ( $p=0.862)$. There was no difference between the hospitals' ability to write reports to the CT scans and the percentage of tomography use $(p=0.470)$.

Regarding tomography usage rates in children with minor head trauma; $6.2 \%(n=19)$ of the participants stated that all children with head trauma underwent routine brain tomography. $23.5 \%(n=72)$ of the participants have written rules about the management of pediatric head trauma patients in their clinics. $39.5 \%(n=121)$ of the physicians were found to make their tomography decision according to the CDMRs designed for children with head trauma. The presence of written rules on the management of pediatric patients with head trauma in the studied clinic did not affect the percentage of tomography use $(p=0.599)$. The criteria that physicians take into consideration when making a tomography decision in children with minor head trauma were given in Figure 2.

The opinions of the participants on some issues related to the use of tomography in the emergency department were taken in the $15^{\text {th }}$ question of our questionnaire. The responses were given in Table 6.

The answers gave by the participants to the question "What do you think is the most important reason for the increase in tomography use" were listed in Table 7.

Of the participants, 53 (17.3\%) were threatened for not taking a CT scan, 59 (19.3\%) were insulted, 1 (0.3\%) was subjected to physical violence, $20(6.5 \%)$ were subjected to verbal and physical violence and 173 (56.5\%) of the participants stated that they did not encounter any verbal or physical attacks.

While $290(94.8 \%)$ of the physicians participated in our study thought that CDMRs are necessary for decision making of tomography in children with minor head trauma, 16 (5.2\%) of them expressed the opposite opinion.

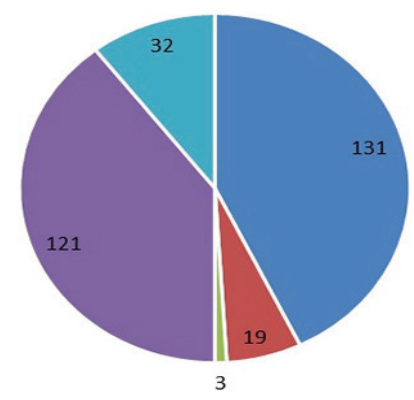

\footnotetext{
= Clinical Experience (42,8\%)

- Consultant Proposal-Expert Advice (6,2\%)

= According to adult head trauma protocols $(1,0 \%)$

= According to clinical decision-making rules designed for children with head injury $(39,5 \%)$

= Undecided $(10,5 \%)$
}

Figure 2: The criteria that physicians take into consideration when making a tomography decision in children with minor head trauma 
Two hundred fifty $(81.7 \%)$ of the physicians gave positive opinions and $56(18.3 \%)$ of them gave negative opinions regarding whether the rate of tomography use will decrease when CDMRs are applied.

\section{Discussion}

Childhood head trauma is a very important public health problem. The number of applications to the emergency department is more than 1.2 million annually due to blunt head trauma in the United States. More than 500 thousand of them are children under the age of 15 . The number of pediatric patients admitted to the emergency department increases each year due to head trauma $(5,7)$. Although rates of TBI-related emergency department visits increased by $70 \%$, the hospitalization rates only have increased by $11 \%$. This is because $75 \%$ of patients visiting the emergency department for head injuries only have mild $\mathrm{TB}$, which do not require hospital admission for observation or any intervention (2). Computed cranial tomography (CCT) is the gold standard diagnostic method for determining $\mathrm{TBI}$ in patients with head injury (8). It has a rapid acquisition time, is easy to interpret, it has reliable results, it can identify TBIs rapidly and accurately, potentially reducing morbidity and mortality (9). CCT is not optimal for all patients because there are lots of

\begin{tabular}{|c|c|c|}
\hline & Agree & Disagree \\
\hline $\begin{array}{l}\text { Tomography increases the risk of cancer in } \\
\text { children }\end{array}$ & 241 & 65 \\
\hline $\begin{array}{l}\text { The smaller the age, the higher the risk of } \\
\text { radiation-induced cancer }\end{array}$ & 206 & 100 \\
\hline $\begin{array}{l}\text { The families' request for tomography affects } \\
\text { my decision }\end{array}$ & 186 & 120 \\
\hline Fear of malpractice affects my decision & 229 & 77 \\
\hline $\begin{array}{l}\text { The educational level of the families affects } \\
\text { my tomography decision }\end{array}$ & 157 & 149 \\
\hline $\begin{array}{l}\text { Easy accessibility of tomography increases } \\
\text { the rate of tomography }\end{array}$ & 190 & 116 \\
\hline $\begin{array}{l}\text { Shortage of space in stay unit increases the } \\
\text { rate of tomography request }\end{array}$ & 112 & 194 \\
\hline
\end{tabular}

Table 7: The answers gave by the participants to the question "What do you think is the most important reason for the increase in tomography use?"

\begin{tabular}{|lll|}
\hline Replies & Frequency & Percentage \\
\hline Fear of malpractice & 112 & 56.2 \\
\hline Family pressure and concerns & 68 & 22.2 \\
$\begin{array}{l}\text { To conclude the patients quickly } \\
\text { in a busy working environment }\end{array}$ & 25 & 8.2 \\
\hline $\begin{array}{l}\text { Being easily accessible to } \\
\text { tomography }\end{array}$ & 20 & 6.5 \\
\hline $\begin{array}{l}\text { Other reasons } \\
\text { Total }\end{array}$ & 21 & 6.9 \\
\hline
\end{tabular}

trauma patients, but a few of them have intracranial pathology (3). It has been reported in studies that only $4.1 \%$ of patients with minor head trauma undergoing tomography had TBI and $0.6 \%$ had surgical intervention (10). Also, tomography costs are high and children need to be transported to an environment other than the emergency room to be applied. Sedation is often required for tomography in children, and most importantly, children are exposed to radiation during shooting (9).

Nowadays brain CT is performed in the majority of patients presenting with head trauma and since the access to tomography is easier all around the world, the imaging is increasing significantly (7). Therefore, CDMRs have been developed for children with minor head trauma to safely and efficiently reduce the rate of tomography use without harming patients in recent years (11). Several studies were published and several protocols were recommended in many countries. PECARN is used in the United States, CHALICE in the UK, and the CATCH in Canada $(4,12)$. PECARN is the most commonly used in the world and our country (13).

In this study we conducted for physicians who decide on the management of pediatric patients with head trauma, we investigated their applications in pediatric patients with minor head trauma, the extent to which they use the prepared guidelines, and the factors that they are affected when making a CT decision. Our study is the first study investigating the tomography usage rate of emergency medicine physicians in Turkey in minor head trauma in the pediatric age group, the frequency of application of CDMRs, and the factors that cause tomography overuse. Previous studies were related to the awareness and validation of CDMRs.

Clinicians were most likely to obtain CT scans, despite low suspicion of clinically important TBI (5). In a prospective cohort study conducted by Osmond et al. (10) it was reported that $52.8 \%$ of 3,866 children who applied to their clinics due to minor head trauma underwent CCT at the time of admission and the remaining 1,823 (47.2\%) patients were discharged directly from the emergency department. In another retrospective study conducted by Stein (14), 1,538 patients applied with minor head trauma whose GCSs were 15 and experienced temporary amnesia after trauma routinely underwent $\mathrm{CCT}$, but no pathology was observed in 1339 (87.1\%) of these patients. Information about the indications for the taking of CCT could not be found in this article. Only $6.2 \%(n=19)$ of physicians who participated in our study directly apply CCT without any criteria for minor head trauma patients admitted to the emergency department. A study of Di et al. (15) included emergency physicians and neurosurgeons in China found that brain tomography was overused and this rate was around $90 \%$. In our study, 34.1\% of physicians stated that they request CCT more than 50\% of their patients. In a prospective cohort analysis by Kuppermann et al. (13), records of 42,412 minor head trauma pediatric patients 
admitted to their center were examined, and was found that 14969 (35.3\%) of these patients were requested CCT. In our study, only $33.9 \%$ of physicians took CCT in children with minor head trauma at a similar rate with this literature.

Although the use of CCT in moderate and severe pediatric head trauma has been accepted in the literature, the indications for the use of CCT in minor head trauma are still controversial (16). In a survey conducted by Eagles et al. (17), 86\% of the emergency medicine physicians working in Canada were aware of the established CDMRs related to head trauma, however, the usage rate of these rules was found to be about 57\%. In the same study, it was stated that physicians in the USA knew these rules at a rate of $66 \%$, but only $21 \%$ applied these rules. Özan and Ataç (18) organized a study among the physicians who work in Turkey and care for adult head trauma patients, it was found that $60.2 \%$ of emergency physicians were aware of CDMRs that have been created for adult head trauma and $52.7 \%$ of them applied these rules. Also in our study, it was seen that $63.7 \%$ of the physicians were aware of the CDMRs for pediatric head trauma patients and $39.5 \%$ of them applied these rules.

There may be several different reasons why tomography usage percentages are found to be higher in women in our study. As female physicians are physically more delicate, they may be more exposed to the imaging insistence of patients' relatives. Tomographic imaging rates may be higher in women in order not to argue with patient relatives and not to be exposed to verbal or physical attacks.

Percentages of asking tomography and application rate of CDMRs were similar in all institutions and all titles. We expected to have lower tomography usage rates in university hospitals. Due to the lack of a gradual referral system in our country, patients can apply to the hospital that they want. For this reason, hospitals in our country have similar characteristics and number of patients. Since there is no national guideline to be followed by physicians when making a tomography decision, these recommended guidelines may be less assumed and used.

Tomography requests were higher in the Southeastern Anatolia region in our study. There are large families in this region and people act together. This situation causes the presence of a large number of relatives together with the patient in the hospitals. Security precautions in this region may be insufficient in moving a large number of patients' relatives away from the emergency room. As a result, this condition may create pressure on physicians' decisions.

There was no difference between the years of professional experience of the physicians who filled our questionnaire and the percentage of tomography requests. However, the criteria that physicians were concerned about making tomography decisions were different. Physicians, whose professional experience was between 0-1 years were mostly acting with the recommendation of a consultant physician and less apply CDMRs. It was determined that verbal and physical assault events experienced by physicians were also higher in the first year of the profession. The reasons for these may be those newly graduated physicians may have less confidence in managing the crowded emergency department. Additionally, they may not have sufficient experience in making quick and accurate decisions and dealing with impatient patient relatives. It may be beneficial to organize in-service training programs about emergency department management and communication with patients' relatives for physicians with limited experience. Also, creating pocket cards with clinical decision-making algorithms can provide ease of use. Written CDMRs in a certain place may not be useful in overcrowded clinics. Because no significant difference was found between the physicians who had written decision-making rules in their clinic and those who had not in terms of tomography use in our study.

In our study, it was determined for the first time that the crowd in hospitals was an important factor in tomography overuse. As the number of patients examined daily in hospitals increased, the rates of tomography requests were found to increase. In subgroup analysis, it was determined that the number of patients examined daily more than 1000 significantly increased the tomography request percentages. One of the reasons for this may be the physician's thought of providing patient circulation in the emergency room. Because the physicians participating in our survey reported that to conclude the patient quickly in the busy working environment in the third place among the reasons for the tomography overuse. It has been determined that the people who work in hospitals where the number of patients examined daily is 1500 and above are exposed to more verbal and physical attacks. The crowded environment may increase the agitation of patients and their relatives. To reduce unnecessary examinations and imaging, measures should be taken to reduce the number of patients examined in the emergency departments daily. Measures such as the more active use of the family medicine departments and the establishment of a phased referral system may help in this regard.

Although there are many publications in the literature about the necessity of CDMRs in pediatric patients with head trauma, there are not enough studies performed among physicians related to the usage of them. In our study, $42.8 \%$ of the participants stated that they decided to make CCT according to their clinical experience and $94.8 \%$ of the physicians agreed on the necessity of CDMRs. Although the majority of physicians confirm the necessity of CDMRs, the low rate of clinical use indicates that other factors are also effective in this regard. The most common factors that physicians participated in our survey complained were the fear of malpractice and the request of the families to take CCT. In the study, Özan and Ataç (18) reported 
that malpractice anxiety was seen in $73.6 \%$ of the emergency department physicians as the reason for not applying CDMRs in minor head injury in adults. This rate was similar (75.5\%) in our study. The rate of emergency physicians who decided upon the expectations of patients and/or their relatives about taking CCT was $72.6 \%$ in the same study (18). The rate of the participants who thought that the family's request to take a CT scan affected their decision was found to be $60.1 \%$ in our study. We believe that the proportional difference is due to the fact that our study included only pediatric patients and physicians were more careful when making imaging decisions because of the negative effects of radiation on children.

There are strong recommendations comparing the prediction rules and clinical suspicion before the widespread use of the CDMRs. Understanding the performance of the prediction rules by comparing them with clinical suspicion can help clinicians adopt these rules and increase the use of appropriate CT in pediatric patients with blunt head injury (5). The majority of physicians also think that CDMRs are necessary and effective in our study.

\section{Study Limitations}

Our study has some limitations. Firstly, the tomography usage percentages stated by the physicians participating in the study are subjective and approximate. It may not precisely reflect the actual proportions. There is no national guideline that determines the criteria for tomographic imaging in children with minor head trauma in our country. While investigating the rate of using CDMRs, it is not questioned which country's algorithm is used by the physicians. Our survey covers physicians working in hospitals in city centers and does not contain information about the approaches in the districts.

Participation from all geographic regions of Turkey is important to reflect the national data on this subject and this is one of the strengths of our study. It is also important that it is the first study about this issue and may shed light on future studies.

\section{Conclusion}

Our study contains valuable data about emergency doctors' tomography requesting rates in pediatric patients with minor head trauma, awareness of CDMRs, and their usage rates and other factors that cause of tomography overuse. Although the majority of our participants were aware of the CDMRs, the rate of application of these rules was still low. Physicians mostly use their own clinical experience when deciding to take CCT to pediatric patients with minor head trauma. The most important reasons for this were medicolegal concerns, the families' insistence on CCT, and the patient's overcrowdedness in the emergency department.
Thus, to increase the awareness of CDMRs, it may be beneficial to organize in-service training programs especially for physicians in the first year of the profession. With the creation and standardization of national clinical decisionmaking algorithms in our country, establishing the necessary legal arrangements in this regard may reduce the medicolegal concerns of physicians. We believe that raising public awareness by creating public service announcements about the negative effects of radiation on children will reduce families' insistence on tomographic imaging and therefore violent incidents. Thus unnecessary imagings, workload, and health-care costs can be reduced.

\section{Ethics}

Ethics Committee Approval: Ethical approval was obtained from Kahramanmaraş Sütçü İmam University Faculty of Medicine Clinical Research Ethics Committee (date: 10.10.2018, approval number: 2018/08/01).

Informed Consent: Participants were informed about the study. Participation was provided on a voluntary basis.

Peer-reviewed: Externally peer reviewed

\section{Authorship Contributions}

Concept: Ö.G, M.K.G., Design: Ö.G., M.K.G., Data Collection or Processing: M.K.G., H.H., A.I.K, M.T., C.Ö., E.E., Analysis or Interpretation: Ö.G., M.K.G., Literature Search: Ö.G., M.K.G., H.H., A.I.K, M.T., C.Ö., E.E., Writing: Ö.G., M.K.G.

Conflict of Interest: There is no conflict of interest.

Financial Disclosure: There are no financial supports.

\section{References}

1. Marin JR, Weaver MD, Barnato $A E$, et al. Variation in emergency department head computed tomography use for pediatric head trauma. Acad Emerg Med. 2014;21:987-995.

2. Azim $A$, Jehan $F S$, Rhee $P$, et al. Big for small: Validating brain injury guidelines in pediatric traumatic brain injury. J Trauma Acute Care Surg. 2017;83:1200-1204.

3. Durgun $H M$, Tektas $E$, Zengin $Y$, et al. Are pediatric emergency care applied research network rules (PECARN) sufficient for computed cranial tomography decision in pediatric patients with mild head trauma? J Clin Exp Invest. 2016;7:35-40.

4. Singh $N$, Singhal A. Challenges in minor TBI and indications for head CT in pediatric TBI-an update. Childs Nerv Syst. 2017;33:1677-1681.

5. Atabaki SM, Hoyle JD Jr, Schunk JE, et al. Comparison of Prediction Rules and Clinician Suspicion for Identifying Children With Clinically Important Brain Injuries After Blunt Head Trauma. Acad Emerg Med. 2016;23:566-575.

6. Oakley $E$, May $R$, Hoeppner $T$, et al. Computed tomography for head injuries in children: Change in Australian usage rates over time. Emerg Med Australas. 2017;29:192-197.

7. Blackwell CD, Gorelick M, Holmes JF, et al. Pediatric head trauma: changes in use of computed tomography in emergency departments in the United States over time. Ann Emerg Med. 2007;49:320-324.

8. Atmıs A, Tolunay 0, Çelik T, et al. Dilemma in Pediatric Head Trauma: Is Cranial Computed Tomography Necessary or Not in Minor Head Traumas? J Pediatr Emerg Intensive Care Med. 2016;3:27-31. 
9. Abouzeid A, Shaban M, Emam T, et al. Evaluation of Computed tomography (CT) scan ordering in children with mild head injury at Emergency Department at Suez Canal University Hospital. Int J Surg Med. 2018;4:7-12.

10. Osmond MH, Klassen TP, Wells GA, et al. CATCH: a clinical decision rule for the use of computed tomography in children with minor head injury. CMAJ. 2010;182:341-348.

11. Burns EC, Grool AM, Klassen TP, et al. Scalp Hematoma Characteristics Associated With Intracranial Injury in Pediatric Minor Head Injury. Acad Emerg Med. 2016;23:576-583.

12. Da Dalt L, Parri N, Amigoni A, et al. Italian guidelines on the assessment and management of pediatric head injury in the emergency department. Ital J Pediatr. 2018;44:7.

13. Kuppermann N, Holmes JF, Dayan PS, et al. Identification of children at very low risk of clinically-important brain injuries after head trauma: a prospective cohort study. Lancet. 2009;374:1160-1170.

Appendix 1: The entire questionnaire
1- Age
2- Gender
Male ( )
Female ( )
3- Institution you work for
State ( )
University ( )
Special ( )
4- Your title
General Practioner ( )
Emergency Medical Specialist ( )
Research Asistant ( )
Faculty Member ( )

5- In which geographical region do you work?

6 - How many years have you been working in this branch?

7- What is the average daily number of patients examined in your

clinic?

$<500$

$500-1000$

$1000-1500$

$>1500$

8- Can computerized tomography be performed 24 hours in your

clinic?

Yes ( )

No ()

9- Is a radiology report written on the tomographies you have taken?

Is written 24 hours

Is written during working hours

The report is not written, but a verbal report is received for emergency cases.

The report is not written

10- Is tomography routinely performed for all children who apply with head trauma in the clinic where you work?

Yes ( )

No ()

11- How many percent of pediatric patients do you perform tomography who apply with a head injury?

12- Are there written rules about the management of pediatric patients with head trauma in the clinic you are working in?

Yes ( )

No ()
14. Stein SC. Minor head injury: 13 is an unlucky number. J Trauma. 2001;50:759-760.

15. Di F, Gao O, Xiang J, et al. Clinical Practice Experiences in Diagnosis and Treatment of Traumatic Brain Injury in Children: A Survey among Clinicians at 9 Large Hospitals in China. PLoS One. 2015;10:e0142983.

16. Kocyigit A, Serinken $M$, Ceven $Z$, et al. A strategy to optimize CT use in children with mild blunt head trauma utilizing clinical risk stratification; could we improve CT use in children with mild head injury? Clin Imaging. 2014;38:236-240.

17. Eagles D, Stiell IG, Clement CM, et al. International survey of emergency physicians' priorities for clinical decision rules. Acad Emerg Med. 2008;15:177-182.

18. Özan E, Ataç GK. Computed tomography use in minor head injury: attitudes and practices of emergency physicians, neurosurgeons, and radiologists in Turkey. Ulus Travma Acil Cerrahi Derg. 2018;24:121-128.

\section{Appendix 1 continued}

13- How do you decide to take tomography in pediatric patients with minor head trauma?

Based on Clinical Experience ( )

According to consultant and expert physicians recommendations () According to adult head injury protocols ( )

According to the clinical decision-making rules designed for children with head injury ( )

Undecided ()

14- Have you ever heard of clinical decision making rules designed for children with head trauma (CATCH, PECARN; CHALICE) before? I did not hear ( )

I heard, but I don't use them ()

I use them sometimes ( )

I don't use ()

15- Can you indicate your opinion on the following items?

Tomography increases the risk of cancer in children ( )

The risk of radiation-induced cancer increases as the child's age decreases ( )

Families' tomography request affects my tomography decision ( )

Fear of malpractice affects my tomography decision ( )

The easy accessibility of tomography increases the tomography usage rate ( )

The lack of space in the observation room increases the tomography usage rate ( )

16- What do you think is the most important reason for increasing tomography use? Please specify.

17- Have you been exposed to violence because you do not want to request a tomography?

I was threatened ()

I was insulted ()

I was physically attacked ( )

I was exposed to verbal and physical attack ()

I was not exposed to any violence ( )

18- Do you consider the necessity of generally accepted clinical decision-making rules for pediatric patients with minor head trauma?

Yes ()

No ()

19- Do you think that applying clinical decision-making rules will reliably reduce tomography use?

Yes ( )

No ()

PECARN: Pediatric Emergency Care Applied Research Network, CATCH: Canadian Assessment of Tomography for Childhood Head Injury, CHALICE: Children's Head Injury Algorithm for the Prediction of Important Clinical Events 